\title{
JEA
}

\section{FAKTOR YANG MEMPENGARUHI INTERNET FINANCIAL REPORTING (IFR) PADA PEMERINTAH KABUPATEN/KOTA DI SUMATERA BARAT}

\author{
Evin Amaliyah Masra ${ }^{1}$,Vita Fitria Sari ${ }^{2}$ \\ ${ }^{1}$ Alumni Jurusan Akuntansi Fakultas Ekonomi, Universitas Negeri Padang \\ ${ }^{2}$ Jurusan Akuntansi Fakultas Ekonomi, Universitas Negeri Padang \\ *Korespodensi: evinamaliyah@gmail.com
}

\begin{abstract}
This study aims to examine the effect of legislative size, income per capita, and regional expenditure on the internet financial reporting in districts / cities of West Sumatera province for the year of 2016-2018. This research uses agency theory and signalling theory. The number of samples used in the study as many as 19 local government website is calculated based on purposive sampling. Types of data are collected using secondary data. The results of this research suggest that income per capita and regional expenditure have a positive effect on the practice of internet financial reporting. Meanwhile, legislative size has no effect against internet financial reporting practices in the local government website
\end{abstract}

Keywords: internet financial reporting; legislative size; income per capita; regional expenditure

How to cite (APA $6^{\text {th }}$ style):

Masra, E.A, \& Sari, V, F. (2020). Faktor Yang Mempengaruhi Internet Financial Reporting (IFR) Pada Pemerintah Kabupaten/Kota di Sumatera Barat. Jurnal Eksplorasi Akuntansi, 2(2), Seri B, 2757-2771.

\section{PENDAHULUAN}

Kewajiban yang harus ditanggung pemerintah adalah untuk menyampaikan informasi keuangan publik dengan penyampaian yang mudah dan didapatkan oleh masyarakat diwujudkan dalam penggunaan suatu media internet untuk menyampaikan informasi yang telah berkembang pesat, sejalan dengan semakin meningkatnya pula jumlah pengguna internet di tengah masyarakat. Keunggulan yang dimiliki dengan adanya menggunakan internet ialah tidak mengenal dari batas waktu ataupun tempat. Internet financial repoting (IFR) sebenarnya merupakan sebuah publikasi dari laporan keuangan daerah melalui perantara internet yang juga merupakan bagian dari bentuk pertanggung jawaban yang ada dari atas pengelolaan keuangan daerah kepada dan untuk masyarakat.

Praktik internet financial reporting (IFR) digunakan juga sebagai sebuah salah satu perwujudan internet pemerintah dan kemudian terus dikembangkan dalam menyediakan dan juga untuk mengumumkan informasi mengenai beberapa laporan keuangan kepada semua pihak dan masyarakat (Sari, 2016). Dalam pelaporan keuangan pemerintah daerah, baik pihak eksekutif 
maupun legislatif sama-sama berkepentingan untuk memastikan bahwa laporan keuangan pemerintah daerah telah memberikan penjelasan yang memadai mengenai kepatuhan terhadap aturan, informasi kinerja, informasi kondisi keuangan, serta informasi perencanaan dan penganggaran (Novia et.al, 2015).

Penelitian mengenai internet financial reporting (IFR) pada pemerintah disimi juga telah dilakukan kepada dan oleh beberapa peneliti diantaranya penelitian Laswad (2005) yang kemudian menemukan kompetisi politik, tingkat utang, tipe council, visailitas pers dan kekayaan pemerintah sebenarnya berpengaruh terhadap sebuah tingkat pengungkapan IFR keuangan di New Zealand. Style (2007) menemukan ukuran daerah, accounting disclosure, pendapatan perkapita dan tingkat hutang sebenarnya juga telah berpengaruh positif terhadap aksesbilitas laporan keuangan di internet pada website pemerintah di United State. Adapun penelitian serupa pun juga telah dilakukan di Indonesia seperti Puspita (2012), Wau (2015), Alhajriana (2017), Verawati (2017), Rahman (2013), Nosihana (2016), Kholifah (2018) dan masih banyak lagi. Khusus untuk propinsi Sumatera Barat terdapat indikasi bahwa internet financial reporting (IFR) belum berjalan optimal. Riset Agustin (2014) menemukan bahwa belum seluruh pemkab/pemkot di propinsi Sumatera Barat memanfaatkan menu transparansi pengelolaan anggaran (TPA) dalam website resmi pemerinta daerah untuk mempublikasikan secara lengkap dan konsisten jenis dokumen-dokumen terkait dengan penggunaan anggaran. Meskipun sebagian besar website Kabupaten di Sumatera Barat telah terdapat menu khusus/link bernama TPA (transparansi pengelolaan anggaran) untuk mendownload informasi atau dokumen keuangan dan kinerja tetapi menu khusus dan link tersebut terkadang kosong, tidak memuat secara lengkap, dan tidak dipublikasikan secara konsisten setiap tahunnya.

Bahkan riset Agustin dan Arza (2019) menemukan anomali antara akuntabilitas dan transparansi publik terkait dengan manajemen pengelolaan keuangan daerah. Akuntabilitas publik telah meningkat dalam 7 tahun terakhir (2012-2019), dimana seluruh pemerintah kabupaten/kota di propinsi Sumatera Barat mempublikasikan pada website resmi maupun media massa setiap opini WTP dari BPK atas LKPD. Namun perilaku serupa tidak terjadi dalam konteks transparansi publik, dimana hampir setengah dari 19 pemerintah kabupaten/kota di propinsi Sumatera Barat yang bersedia mengungkapkan secara terbatas dokumen-dokumen terkait pengelolaan anggaran daerah (hanya 5-7 dokumen dari total 12 dokumen).

Faktor yang mempengaruhi internet financial reporting (IFR) salah satunya adalah ukuran pemerintah. Ukuran pemerintah adalah sebuah skala yang kemudian dapat memperlihatkan seberapa besar atau kecilnya sebuah keadaan dari pemerintah daerah (Hartono, 2014). Internet Financial Reporting (IFR) sebenarnya juga berfungsi untuk melihat dan meudahkan pemerintah daerah dalam mencoba untuk mengatasi dan kemudian menekan besarnya biaya dari pemantauan karena sebenarnya penggunaannya dari yang efisien khususnya juga bagi masyarakat. Hal tersebut didukung oleh penelitian Wau (2015), Nosihana (2016), Puspita (2012) dan Pitri (2017) yang menunjukan bahwa ukuran dari pemerintah sebenarnya juga berpengaruh pada sebuah pelaporan di dalam internet financial reporing (IFR). Hasil berbeda ditemukan dalam penelitian Laswad (2005) tidak ditemukan apakah adanya hubungan positif dari ukuran pemerintah dengan praktik internet financial reporting (IFR).

Faktor selanjutnya yang mungkin mempengaruhi internet financial reporting (IFR) adalah Pendapatan Daerah Regional Bruto (PDRB) perkapita. PDRB adalah jumlah yang akan muncul dari seluruh sektor dari perekonomian yang ada di suatu wilayah itu. PDRB perkapita juga bertujuan untuk melihat seberapa besarnya tingkat dari kesejahteraan kepada masyarakat dalam suatu dan sebuah daerah (www.bps.go.id). Pendapatan perkapita yang juga semakin tinggi 
akan dapat mengakibatkan masyarakat harus melakukan monitoring politik yang kemudian semakin tinggi pula sehingga kemudian tekanan yang akan diberikan untuk dalam hal menyediakan informasi publik semakin besar (Styles, 2007). Hal tersebut kemudian mendorong pemerintah untuk menyediakan informasi dari keuangan dalam website. Penelitian yang dilakukan oleh Wau (2015) dan Pitri (2017) menyatakan pendapatan perkapita memiliiki pengaruh terhadap sebuah dari pelaporan atas internet financial reporting, sedangkan Kholifah (2018) menunjukan bahwa PDRB perkapita tidak berpengaruh terhadap adanya internet financial reporting (IFR).

Faktor selanjutnya yang mempengaruhi internet financial reporting (IFR) adalah belanja daerah. Belanja daerah sebenarnya adalah keharusan dan beban dari pemerintah daerah yang kemudian jumlahnya harus mulai diakui sebagai bentuk dalam hal mengurangi sebuah nilai dari daerah. Belanja daerah yang kemudian semakin tinggi juga akan kemudian mulai berdampak mungkin pada anggaran dari daerah yang sebenarnya seharusnya menunjukan apakah pihak dari pemerintah daerah telah melakukan dan mempergunakan hal anggaran daerah untuk kepentingan dari masyarakat. Hal tersebut kemudian telah dibuktikan oleh penelitian Pitri (2017) dan Alhajriana (2017) yang menyebutkan bahwa belanja daerah memiliki pengaruh positif terhadap internet financial reporting. Pemerintah yang melakukan internet financial reporting (IFR) menunjukan bahwa anggaran dari belanja daerah telah digunakan selaras dan sesuai dengan apa saja aturan yang mugkin berlaku. Berbeda dengan penelitian Puspita (2012) menunjukan tidak terdapat dan tidak terlihat hubungan positif antara belanja dari daerah dengan internet financial reporting (IFR).

Fenomena terkait dengan internet financial reporting (IFR) adalah kurangnya partisipasi pemerintah daerah dalam transparasi pelaporan keuangan di website pemerintah daerah. Kementrian Dalam Negeri telah mengeluarkan Instruksi Menteri Dalam Negeri tentang Peningkatan Transparansi Pengelolaan Anggaran Daerah, Peraturan terseut sebenarnya dibuat dan dirancang dalam hal mendorong daerah dalam hal untuk menyampaikan transparansi dari anggaran di website pemerintahan. Peraturan tersebut sebenarnya juga menyuruh para Gubernur untuk mengaturkan kepada para kepala daerah di wilayah masing-masing yang sebenarnya belum memiliki website dan kemudian pemerintah dari yang telah memiliki website resmi untuk berusaha menyiapkan menu dari konten yang disebut dengan nama Transparansi Pengelolaan Anggaran Daerah (TPAD).

Menurut sumber data yang diolah tahun 2019, pemerintah kabupaten/kota Sumatera Barat sebenarnya sudah memiliki website resmi, sebesar $47,4 \%$ pemerintah daerah di Sumatera Barat telah menyediakan menu Transparansi Pengelolaan Anggaran Daerah (TPAD) atas ketersediaan informasi keuangan daerah di website pemerintah daerah. Sementara 52,6\% pemerintah daerah masih belum menyediakan link atau menu Transparansi Pengelolaan Anggaran Daerah (TPAD) tersebut. Hal tersebut juga menjelaskan bahwa tidak seluruhnya pemerintah daerah di Sumatera Barat menyediakan telah informasi semua keuangan dari daerah pada website masing-masing. Alasan kebanyakan pemerintah daerah yang masih saja belum mencoba melakukan praktik internet rinancial reporting (IFR).

Penelitian ini sebenarnya merujuk kepada penelitian dari Nosihana (2016) dengan judul internet financial reporting (IFR) dan Faktor-Faktor apa saja yang mungkin Mempengaruhi Pemerintah dari Kota dan Kabupaten yang ada di Indonesia. Berdasarkan kepada uraian dari latar belakang di atas dan kepada masalah yang telah ditemukan maka penulis mulai tertarik untuk mencoba melakukan sebuah penelitian lebih lanjut dengan judul "Faktor-Faktor yang 


\section{Mempengaruhi Internet Financial Reporting (IFR) pada Pemerintahan Kabupaten / Kota di Sumatera Barat".}

\section{REVIU LITERATUR DAN HIPOTESIS \\ Teori Keagenan (Agency Theory)}

Teori Agensi adalah suatu dari bentuk hubungan diantara dua atau sebenarnya lebih dari pihak yang mana kemungkinan salah satu dari pihak dapat juga disebut dengan agen dan kemudian dari pihak lain juga dapat disebut sebagai bagian. Teori ini sebenarnya mencoba mengatasi apakah akan adanya perbedaan yang memengaruhi kepentingan yang mungkin dialami oleh para kedua belah pihak hal itu dengan mencoba menyediakan sebuah informasi dari keuangan yang mungkin juga berpengaruh baik sehingga kita dapat pula mencoba menambah keuntungan, serta kemudian juga mempertimbangkan apakah adanya kerugian yang mungkin juga akan terjadi (Jensen, 1976).

Terdapat dua pihak yang mungkin dapat melakukan sepakat, pihak tersebut kemudian kemungkinan bisa saja muncul ketika salah satu dari pihak mencoba untuk menyerahkan atau memberikan tugas dan tanggung jawab itu kepada para pihak lain untuk melakukan tindakan pengambilan keputusan. Banker (1987) menjelaskan didalam suatu Negara akan adanya hubungan antara pimpinan pemerintahan dengan masyarakat hal ini kemudian dapat disebut sebagai hubungan agensi. Pemerintah akan mencoba bereaksi sebagai agen dalam menjalankan segala dari urusan pemerintahan sesuai dengan aa saja kepeerluan dari masyarakat yang berlaku juga sebagai prinsipal.

\section{Teori Signaling (Signalling Theory)}

Teori signalling dalam ruang lingkup pemerintahan mengatakan sebenarnya pemerintah daerah yang mungkin telah diberikan amanat oleh para masyarakat mempunyai kemauan untuk memperlihatkan adanya hasil dari yang bagus kepada para pihak masyarakat. Wau (2015) mengatakan teori signalling dapat menolong pemerintah dan juga pihak masyarakat dalam mengurangi adanya kesalahan dari informasi. Pemerintah kemudian juga harus mencoba dan menghilangkan adanya kesalahan dari informasi dengan cara mencoba memberikan sebuah bukti yang baik kepada masyarakat melalui pengungkapan laporan dari keuangan yang lengkap dan berbobot.

\section{Internet Financial Reporting (IFR)}

Internet Financial Reporting sebenarnya ialah suatu dari bentuk keharusan pemerintah atas laporan yang telah dikelolanya melalui internet (Verawati, 2017). Praktik Internet Financial Reporting (IFR) sebagai salah satu wujud internet pemerintah terus dipacu untuk menjadikan enataan pemerintahan yang leih berkualitas dan terpercaya maka kemungkinan diperlukan adanya dan efisiensi manajemen dan sistem pemerintahan internet. Internet Financial Reporting atau pelaporan keuangan di internet merupakan suatu bentuk pertanggungjawaban pemerintah atas anggaran yang telah dikelolanya melalui internet (Verawati, 2017).

Menurut Government Finances Officers Assosiation (2009) terdapat beberapa keleluasaan memnyebarluaskan laporan dari informasi keuangan di situs pemerintah daerah seperti, meningkatkan keinginan pemerintah terhadap para pemakai informasi dari keuangan, akses keseluruhan bagi semua pemakai informasi dari keuangan, meningkatkan interaksi dengan pengguna informasi keuangan, meningkatkan kemudahan dan, hemat pengeluaran serta mengurangi pemakaian dari kertas yang telah terjadi. 


\section{Ukuran Pemerintah}

Ukuran dari pemerintah mengarah pada seberapa besar organisasi. Pemerintah daerah dengan ukuran yang besar sangat diinginkan dapat mampu memberikan layanan yang baik kepada banyak pihak. keinginan serta keharusan terhadap pemerintah daerah akan memicu dari kinerja dari arah pemerintah daerah yang lebih baik. Menurut Maiyora (2015. Pemerintah daerah yang memiliki ukuran dari aset yang besar akan memiliki yang besar pula untuk melakukan pennyampaian informasi dari keuangan pemerintah di daerah. Informasi yang terdapat ada sebuah dalam laporan pertanggungjawaban atau pelaporan dari keuangan pemerintah daerah dapat dipakai sebagai salah satu pembantu untuk mencari dari besarnya kinerja keuangan pemerintah daerah (Abdullah, 2013).

\section{PDRB Perkapita (Pendapatan Perkapita)}

PDRB adalah jumlah yang muncul dari semua dari sektor perekonomian di sebuah wilayah. PDRB perkapita untuk melihat seberapa besarnya tingkat kemajuan dari masyarakat dalam suatu daerah (www.bps.go.id). Semakin besar pendapatan semakin besar pula permintaan. Pendapatan perkapita yang semakin tinggi akan menjadikan masyarakat melakukan monitoring politik yang akhirnya semakin tinggi pula sehingga keharusan yang diberikan untuk menyediakan informasi keada public juga akan menjadi semakin besar (Styles, 2007). Maka alasan tersebut memuat pelaporan dari keuangan dalam website.

\section{Belanja Daerah}

Belanja daerah sebenarnya adalah keharusan dan beban dari pemerintah daerah yang kemudian jumlahnya harus mulai diakui sebagai bentuk dalam hal mengurangi sebuah nilai dari daerah. Belanja daerah yang kemudian semakin tinggi juga akan kemudian mulai berdampak mungkin pada anggaran dari daerah yang sebenarnya seharusnya menunjukan apakah pihak dari pemerintah daerah telah melakukan dan mempergunakan hal anggaran daerah untuk kepentingan dari masyarakat, artinya mungkin keinginan dari pemerintah daerah pun juga akan terlihat semakin meningkat pula hanya untuk menyampaikan hal laporan dari keuangannya kepada masyarakat yang bahkan melalui dari website dari pemerintah tersebut (Alhajriana, 2017)

\section{Pengaruh Ukuran Pemerintahan Terhadap Internet Financial Reporting (IFR)}

Ukuran pemerintah adalah sebuah bentuk yang dapat menunjukkan besar kecilnya keadaan pemerintah (Hartono, 2014). Ukuran dari pemerintah mengarah pada seberapa besar organisasi. Pemerintah daerah dengan ukuran yang besar sangat diinginkan dapat mampu memberikan layanan yang baik kepada banyak pihak. keinginan serta keharusan terhadap pemerintah daerah akan memicu dari kinerja dari arah pemerintah daerah yang lebih baik. Menurut Maiyora (2015. Pemerintah daerah yang memiliki ukuran dari aset yang besar akan memiliki yang besar pula untuk melakukan penyampaian informasi dari keuangan pemerintah di daerah. Informasi yang terdapat ada sebuah dalam laporan pertanggungjawaban atau pelaporan dari keuangan pemerintah daerah dapat dipakai sebagai salah satu pembantu untuk mencari dari besarnya kinerja keuangan pemerintah daerah (Abdullah, 2013). (Nosihana, 2016). Hal tersebut sejalan dengan hasil penelitian Wau (2015), Nosihana (2016), Puspita (2012) dan Pitri (2017) yang menemukan adanya pengaruh positif ukuran pemerintah dalam internet financial reporting (IFR). H1: Ukuran pada pemerintahan memiliki berpengaruh positif terhadap internet financial reporting (IFR) pada pemerintah kabupaten/kota di Sumatera Barat 


\section{Pengaruh PDRB Perkapita Terhadap Internet Financial Reporting (IFR)}

PDRB adalah jumlah yang muncul dari semua dari sektor perekonomian di sebuah wilayah. PDRB perkapita untuk melihat seberapa besarnya tingkat kemajuan dari masyarakat dalam suatu daerah (www.bps.go.id). Semakin besar pendapatan semakin besar pula permintaan. Pendapatan perkapita yang semakin tinggi akan menjadikan masyarakat melakukan monitoring politik yang akhirnya semakin tinggi pula sehingga keharusan yang diberikan untuk menyediakan informasi keada public juga akan menjadi semakin besar (Styles, 2007). Maka alasan tersebut memuat pelaporan dari keuangan dalam website. Hal ini didukung penelitian Wau (2015) dan Pitri (2017) yang menemukan pendapatan perkapita berpengaruh terhadap Internet Financial Reporting (IFR).

H2: PDRB Perkapita berpengaruh positif terhadap internet financial reporting (IFR) pada pemerintah kabupaten/kota di Sumatera Barat.

\section{Pengaruh Belanja Daerah Terhadap Internet Financial Reporting (IFR)}

Belanja daerah merupakan kewajiban pemerintah daerah yang jumlahnya diakui sebagai dalam mengurangi nilai kekayaan dari daerah. Belanja daerah yang semakin tinggi berdampak pada anggaran daerah yang seharusnya menunjukan apakah pemerintah daerah telah mempergunakan anggaran daerah untuk kepentingan masyarakat, artinya keinginan pemerintah daerah akan semakin meningkat untuk menyampaikan laporan keuangannya kepada masyarakat bahkan melalui website pemerintah tersebut (Alhajriana, 2017). Hal ini didukung oleh penelitian Pitri (2017) dan Alhajriana (2017) yang menemukan belanja daerah berpengaruh terhadap Internet Financial Reporting.

H3: Belanja daerah berpengatuh positif terhadap internet financial reporting (IFR) pada pemerintah kabupaten/kota di Sumatera Barat.

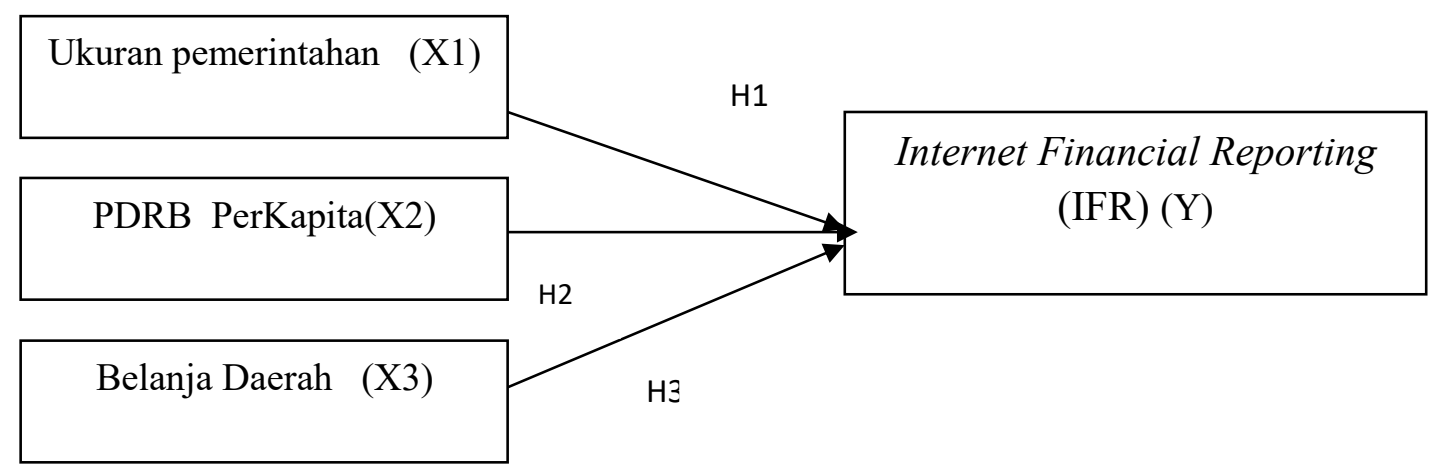

\section{Gambar 1. Kerangka Konseptual}

\section{METODE PENELITIAN}

\section{Jenis dan Populasi Penelitian}

Jenis penelitan yang sebenarnya dipakai ini adalah penelitian kuantitiatif. Desain penelitian ini sebenarnya merupakan sebuah desain kausalitas. Populasi dalam penelitian sebenarnya ini adalah pemerintahan daerah yang ada pada kabupaten/kota yang terletak di Sumatera Barat. Jumlah dari kabupaten dan kota yang dimilki yang ada di Sumatera Barat adalah 19 kota/kabupaten. Pengambilan dari contoh yang akan dilakukan adalah dengan mencoa menggunakan apa saja pilihan pada metode dari ada sampel (purposive sampling). Kriteria yang ditetapkan ialah, pemerintahan pada daerah sebenarnya telah memiliki beberapa laporan pada keuangan audited 
oleh Badan Pemeriksa Keuangan (BPK) karena untuk itu digunakan tahun 2016-2018 serta juga laporan pada keuangan tersebut dapat juga diperoleh di Badan Pemeriksa Keuangan (BPK) dan pemerintahan didaerah sebaiknya harus mempunyaii situs resmi sendiri di internet. Penelitian ini sebenarnya telah memakai data pada sekunder yang sumber yang ada pada data dari penelitiannya yang diterima secara dengan tidak langsung dan juga ditemukan melalui media lainnya. Data pada sekunder tersebut akhirnya juga berupa pada laporan dikeuangan pemerintah pada daerah tahun 2016-2018 yang kemudian telah diaudit oleh pihak Badan Pemeriksa Keuangan (BPK).

\section{Variabel Penelitian dan Pengukuran}

Variabel dependen yang dipakai dalam penelitian ini adalah internet financial reporting (IFR). Internet Financial Reporting (IFR) merupakan variabel dependen yang diukur dengan menggunakan angka dummy. Cara pemberian kode dummy yakni adalah menggunakan kategori yang kemudian dinyatakan dengan memakai angka 1 dan 0 . Kode 1 dipakai untuk pemerintah yang menerapkan Internet Financial Reporting (IFR) dan kode 0 adalah untuk pemerintah yang tidak menerapkan Internet Financial Reporting (IFR). Variabel independen dalam penelitian ini adalah ukuran pemerintah, PDRB perkapita dan belanja daerah. Ukuran pemerintah diproksikan dengan memakai total dari aset (Ln) aktiva). Pendapatan perkapita yang digunakan untuk digunakan dalam penelitian ini adalah menggunakan pendekatan produk domestik regional bruto yang disebut juga (PDRB) perkapita. Produk domestik regional bruto (PDRB) kemudian dibagi dengan jumlah dari penduduk yang ada dalam daerah tersebut. Sementara belanja daerah juga diukur menggunakan Logaritma natural ( $\mathrm{Ln})$ dari total belanja daerah.

\section{Metode Analilis Data}

Analisis data yang ada pada penelitian ini diuji dengan memakai program dari SPSS. Pengujian hipotesis dari penelitian ini kemudian dilakukan untuk melihat pengaruh antara variable independen dan juga dependen maka dengan ini metode yang dipakai adalah analisis kuantitatif yaitu berupa dari teknik analisis regresi berganda dengan memakai rumus sebagai berikut:

$$
\mathrm{Y}=\mathrm{a}+\mathrm{b} 1 \mathrm{x} 1+\mathrm{b} 2 \times 2+\mathrm{b} 3 \times 3+\mathrm{e}
$$

\begin{tabular}{|c|c|}
\hline Dimana: & \\
\hline Y & $=$ Internet Financial Reporting \\
\hline $\mathrm{X} 1$ & $=$ Ukuran pemerintahan \\
\hline $\mathrm{X} 2$ & $=$ PDRB perkapita \\
\hline $\mathrm{X} 3$ & $=$ Belanja daerah \\
\hline & $=$ Konstanta \\
\hline b1, b2, b3 & $\begin{array}{l}=\text { Koefisien regresi masing-masing } \mathrm{x} \\
=\text { Error term }\end{array}$ \\
\hline
\end{tabular}

\section{HASIL DAN PEMBAHASAN}

\section{Analisis Linear Berganda}

Analisis pada regresi dari linear berganda dipakai agar untuk dapat melihatjumlah apakah akan adanya pengaruh yang terdapat pada variable yang bebas kepada variabel yang terikat. Variabel bebas yang digunakan dalam penelitian ini adalah ukuran pemerintahan, PDRB perkapita dan belanja daerah, sedangkan variabel terikat dalam penelitian ini adalah Internet 
Financial Reporting (IFR). Salah satu cara bagaimana untuk melihat adanya pengaruh ukuran pemerintahan, PDRB perkapita dan belanja daerah secara bersama-sama terhadap Internet Financial Reporting (IFR) oleh pemerintahan daerah kabupaten/kota di provinsi Sumatera Barat disajikan dalam tabel 1 sebagai berikut:

Tabel 1. Hasil Analisis Regresi Linear Berganda

Coefficients ${ }^{\mathrm{a}}$

\begin{tabular}{|c|c|c|c|c|c|c|}
\hline & & \multicolumn{2}{|c|}{ Unstandardized Coefficients } & \multirow{2}{*}{\begin{tabular}{|l} 
Standardized \\
Coefficients
\end{tabular}} & \multirow[b]{2}{*}{$\mathrm{T}$} & \multirow[b]{2}{*}{ Sig. } \\
\hline \multicolumn{2}{|c|}{ Model } & B & Std. Error & & & \\
\hline 1 & (Constant) & -96.288 & 35.077 & & -2.745 & .008 \\
\hline & Ukuran Pemda & -1.051 & 1.416 & -.139 & -.742 & 461 \\
\hline & PDRB Perkapita & .116 & .043 & .358 & 2.680 & .010 \\
\hline & Belanja Daerah & 4.560 & 1.883 & .473 & 2.421 & .019 \\
\hline
\end{tabular}

a. Dependent Variable: IFR

Sumber : Lampiran Hasil Pengolahan Data SPSS, 2020

Koefisien determinasi sangat berguna untuk mengetahui adanya kontribusi pengaruh variabel bebas terhadap variabel terikat. Untuk mengetahui dan melihat seberapa besar kontribusi ukuran pemerintahan, PDRB per kapita dan belanja daerah terhadap Internet Financial Reporting (IFR) pada pemerintahan daerah kabupaten/kota di provinsi Sumatera Barat sebagai berikut:

Tabel 2. Uji R Square

\begin{tabular}{|c|c|c|c|c|}
\hline Model & $\mathrm{R}$ & $\begin{array}{c}\text { Squar } \\
\mathrm{e}\end{array}$ & $\begin{array}{l}\text { Adjuste } \\
\text { d R Square }\end{array}$ & $\begin{array}{l}\text { Std. Error of } \\
\text { the Estimate }\end{array}$ \\
\hline & $\begin{array}{ll} & .426 \\
\text { a } & \end{array}$ & 182 & .136 & 3.192 \\
\hline
\end{tabular}

a. Predictors: (Constant), Belanja Daerah, PDRB Perkapita, Ukuran Pemda

b. Dependent Variable: IFR

Sumber : Lampiran Hasil Pengolahan Data SPSS, 2020

\section{Pengujian Hipotesis}

Uji t

Uji t dipakai untuk melihat adanya pengaruh dari tiap masing-masing variabel bebas yang ada terhadap variabel independen dengan variabel dependen. 


\section{Tabel 3}

Uji t

Coefficients $^{\mathrm{a}}$

\begin{tabular}{|c|c|c|c|c|c|}
\hline \multirow[b]{2}{*}{ Model } & \multicolumn{2}{|c|}{$\begin{array}{l}\text { Unstandardized } \\
\text { Coefficients }\end{array}$} & $\begin{array}{l}\text { Standardized } \\
\text { Coefficients }\end{array}$ & & \multirow[b]{2}{*}{ ig. } \\
\hline & B & $\begin{array}{l}\text { Std. } \\
\text { Error }\end{array}$ & Beta & & \\
\hline (Constant) & -96.288 & 35.077 & & 2.745 & 008 \\
\hline Ukuran Pemda & -1.051 & 1.416 & -.139 & .742 & 461 \\
\hline PDRB Perkapita & .116 & .043 & .358 & .680 & 010 \\
\hline Belanja Daerah & 4.560 & .883 & .473 & .421 & 019 \\
\hline
\end{tabular}

a. Dependent Variable: IFR

Sumber : Lampiran Hasil Pengolahan Data SPSS, 2019

\section{Uji F}

Uji F dipakai untuk membuktikan apakah semua dari variabel bebas dalam model berpengaruh secara bersama-sama terhadap variabel yang terikat. Diketahui nilai F hitung pada tabel Anova yaitu sebagai berikut :

\section{Tabel 4}

Hasil Uji Kelayakan (Uji F)

ANOVA $^{b}$

\begin{tabular}{|c|c|c|c|c|c|c|}
\hline \multicolumn{2}{|c|}{ Model } & $\begin{array}{l}\text { Sum } \\
\text { Squares }\end{array}$ & Df & Mean Square & $\mathrm{F}$ & Sig. \\
\hline \multirow[t]{3}{*}{1} & Regression & 119.995 & 3 & 39.998 & 3.926 & $.013^{\mathrm{a}}$ \\
\hline & Residual & 539.900 & 53 & 10.187 & & \\
\hline & Total & 659.895 & 56 & & & \\
\hline
\end{tabular}

a. Predictors: (Constant), Belanja Daerah, PDRB Perkapita, Ukuran Pemda

b. Dependent Variable: IFR

Sumber : Lampiran Hasil Pengolahan Data SPSS, 2020

\section{Uji Asumsi Klasik}

\section{Uji Normalitas}

Untuk melihat pengujian normalitas data yang ada pada penelitian ini dilakukan dengan memakai uji Kolmogorov Sminov dengan hasil sebagai berikut: 
Tabel 5

Uji Normalitas

One-Sample Kolmogorov-Smirnov Test

\begin{tabular}{|ll|l|}
\hline & & $\begin{array}{l}\text { Unstandardized } \\
\text { Residual }\end{array}$ \\
\hline $\mathrm{N}$ & & 57 \\
Normal Parameters $^{\mathrm{a}}$ & Mean & .0000000 \\
& Std. Deviation & .22783069 \\
Most Extreme Differences & Absolute & .175 \\
& Positive & .175 \\
& Negative & -.094 \\
Kolmogorov-Smirnov Z & & 1.323 \\
Asymp. Sig. (2-tailed) & & .060 \\
\hline
\end{tabular}

a. Test distribution is Normal.

Sumber: Lampiran Hasil Pengolahan Data, 2020

Hasil pengujian dari prasyarat normalitas yang diketahui bahwa nilai dari Asym.Sig (2-tailed) untuk semua variabel yang ada dalam penelitian ini sebesar 0,060 yang mana lebih besar dari tingkat signifikan yang digunakan pada penelitian ini $(\alpha=0,05)$, dengan demikian dapat disimpulkan bahwa data yang digunakan dalam penelitian ini telah berdistribusi normal dan bisa dilanjutkan untuk diteliti lebih lanjut karena nilai signifikansi melebihi dari jumlah normalitas $>0,05$.

\section{Uji Heteroskedastisitas}

\section{Tabel 6}

Hasil Uji Heterokedastisitas

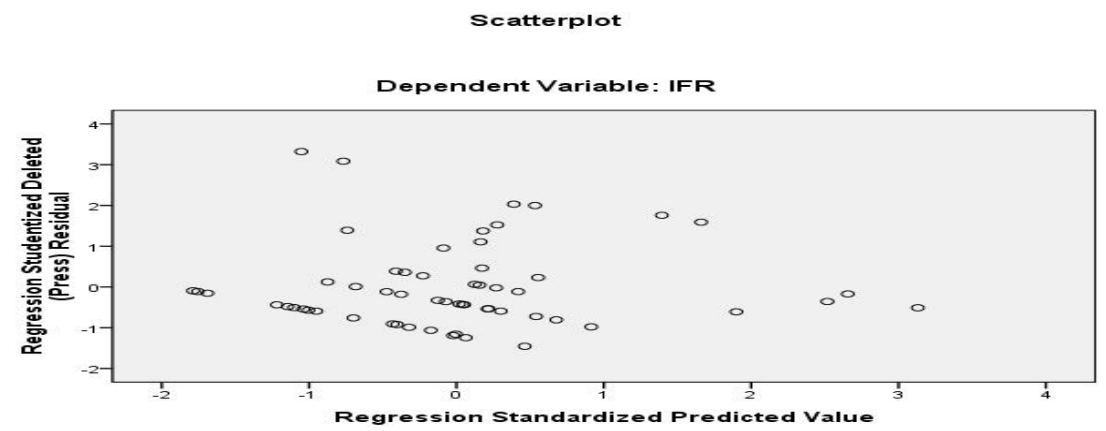

Sumber: Data Sekunder Diolah (2020)

Berdasarkan dengan hasil dari uji heteroskedastisitas yang terdapat pada gambar tidak membentuk sebuah pola, maka dapat disimpulkan tidak terjadi kasus heteroskedastisitas. 


\section{Uji Multikolonieritas}

Tabel 7

Hasil Uji Multikolonieritas

\begin{tabular}{|c|c|c|c|c|c|c|}
\hline \multirow[b]{2}{*}{ Model } & \multicolumn{2}{|c|}{$\begin{array}{l}\text { Unstandardized } \\
\text { Coefficients }\end{array}$} & \multirow[b]{2}{*}{$\mathrm{T}$} & \multirow[b]{2}{*}{ Sig. } & \multicolumn{2}{|c|}{$\begin{array}{l}\text { Collinearity } \\
\text { Statistics }\end{array}$} \\
\hline & B & $\begin{array}{l}\text { Std. } \\
\text { Error }\end{array}$ & & & $\begin{array}{l}\text { Toleran } \\
\text { ce }\end{array}$ & VIF \\
\hline 1(Constant) & 96.288 & 35.077 & -2.745 & .008 & & \\
\hline $\begin{array}{l}\text { Ukuran } \\
\text { Pemerintah }\end{array}$ & 1.051 & 1.416 & .742 & 461 & 441 & 2.266 \\
\hline PDRB Perkapita & 116 & .043 & 2.680 & 010 & .863 & 1.158 \\
\hline Belanja Daerah & 4.560 & 1.883 & 2.421 & .019 & .405 & 2.472 \\
\hline
\end{tabular}

a. Dependent Variable: IFR

Sumber : Lampiran Hasil Pengolahan Data, 2020

Berdasarkan dari hasil pengujian yang ada dalam prasyarat uji multikolonieritas diketahui bahwa data hasil penelitian ini tidak mendapatkan kasus multikolonieritas antara sesama variabel bebas, sehingga pengolahan data dengan regresi linear berganda dapat dilanjutkan.

\section{Uji Autokorelasi}

Tabel 8

Uji Autokorelasi

Model Summary

\begin{tabular}{|c|c|c|c|c|c|}
\hline Model & & $\begin{array}{r}R \\
\text { Square }\end{array}$ & $\begin{array}{l}\text { Adjus } \\
\text { ted } R \\
\text { Square }\end{array}$ & $\begin{array}{l}\text { Std. } \\
\text { Error of the } \\
\text { Estimate }\end{array}$ & $\begin{array}{l}\text { Durbi } \\
\text { n-Watson }\end{array}$ \\
\hline 1 & $\begin{array}{l}4 \\
2 \\
6 \\
a\end{array}$ & .182 & .136 & 3.192 & 2.364 \\
\hline
\end{tabular}

a. Predictors: (Constant), Belanja Daerah, PDRB Perkapita, Ukuran Pemda

b. Dependent Variable: IFR

Sumber : Data Sekunder Diolah (2020)

Dapat dibuktikan bahwa tidak terjadi kasus autokorelasi disebabkan karena nilai Durbin Waston mendekati 2 atau kecil dari 2.

\section{Pembahasan}

Pengaruh Ukuran Pemerintah terhadap Internet Financial Reporting

Ukuran pemerintah adalah sebuah bentuk yang dapat menunjukkan besar kecilnya keadaan pemerintah (Hartono, 2014). Hipotesis pertama yang ditunjukan dalam penelitian ini ialah ukuran pemerintah yang berpengaruh negatif terhadap Internet Financial Reporting (IFR) pada kabupaten/kota yang ada pada provinsi Sumatera Barat. Hal ini juga dapat kita lihat dari hasil 
dari pengujian secara parsial, Nilai t hitung $-0,742$ dan nilai $(\operatorname{sig}=0,461>0,05)$. Dengan $\mathrm{df}=$ $57-3=54$ diperoleh $t_{\text {tabel }}$ sebesar 1,674, dari hasil di atas dapat ambil bahwa $t_{\text {hitung }}<t_{\text {tabel }}$ atau $0,742<1,674$.

Berdasarkan pada sebuah hasil analisis statistik ukuran dalam penelitian ini pada hipotesis pertama (H1) dapat disimpulkan bahwa ukuran pemerintah tidak berpengaruh kepada Internet Financial Reporting (IFR) pada pemerintah kabupaten/kota provinsi Sumatera Barat. Hasil dari penelitian ini juga sesuai dengan penelitian yang telah dibuat oleh Laswad (2005) yang mana tidak melihat adanya hubungan yang positif antara ukuran dari pemerintah daerah dengan ketersediaan Internet Financial Reporting (IFR) yang ada pada pemerintah daerah. Berdasarkan dari hasil pengujian, jumlah aset yang telah dimiliki oleh pemerintah daerah tidak berpengaruh terhadap adanya dorongan dari pemerintah dalam mencoba menyediakan semua informasi keuangannya.

\section{Pengaruh PDRB Perkapita terhadap Internet Financial Reporting}

Hasil penelitian ini juga didapatkan nilai t hitung 2,680 dan nilai $(\operatorname{sig}=0,010<0,05)$. Dengan df $=57-3=54$ diperoleh $t_{\text {tabel }}$ sebesar 1,674, dari hasil di atas dapat dilihat bahwa $t_{\text {hitung }}>t_{\text {tabel }}$ atau 2,680 > 1,674, maka variabel PDRB perkapita berpengaruh terhadap Internet Financial Reporting (IFR) dalam pemerintahan daerah yang adadi kabupaten/kota di provinsi Sumatera Barat. Berdasarkan pada hasil dari sebuah uji dari hipotesis tersebut PDRB perkapita memiliki pengaruh positif terhadap transparansi dari adanya informasi keuangan daerah. Semakin tinggi tingkat sebuah kesejahteraan dalam masyarakat maka sebuah pengungkapan transparansi informasi keuangan pada daerah akan mulai semakin besar, hal ini dapat juga disebabkan oleh adanya adanya political monitoring oleh masyarakat dan juga terdapat semakin tinggi pula permintaan informasi pada kinerja pemerintah daerah pada website pemerintah daerah. Hasil ini kemudian konsisten dengan penelitian yang dibuat oleh Laswad (2005) yang menemukan bahwa adanya hubungan yang dibuktikan positif antara kekayaan pemerintah daerah yang dihubungkan dengan pendapatan perkapita terhadap adanya ketersediaan dari Internet Financial Reporting (IFR) oleh pemerintah daerah.

\section{Pengaruh Belanja Daerah terhadap Internet Financial Reporting}

Hasil dari penelitian bahwa ditemukan nilai Nilai t hitung 2,421 dan nilai $(\operatorname{sig}=0,019<0,05)$. Dengan $\mathrm{df}=57-3=54$ diperoleh $\mathrm{t}_{\text {tabel }}$ sebesar 1,674, dari hasil di atas dapat dilihat bahwa $\mathrm{t}_{\text {hitung }}>$ $\mathrm{t}_{\text {tabel }}$ atau 2,421 > 1,674, maka variabel belanja daerah terdapat berpengaruh terhadap Internet Financial Reporting (IFR) oleh Pemerintahan Daerah Kabupaten/Kota di Provinsi Sumatera Barat. Hasil penelitian ini sejalan dengan penelitian yang dilakukan oleh Pitri (2017) dan Alhajriana (2017) yang menemukan bahwa belanja dalam daerah berpengaruh terhadap Internet Financial Reporting yang menunjukan bahwa tingkat dari belanja didaerah yang tinggi pada suatu daerah juga dapat akan mendorong pemerintah daerah untuk mengungkapkan informasi keuangan yang juga tinggi pada pada website pemerintah didaerahnya masing-masing. Hal ini kemudiandapat disebabkan bahwa belanja daerah suatu daerah yang tinggi yang kemudian dapat mencerminkan tingkat pelayanan yang tinggi pula, sehingga belanja daerah otomatis akan dapat berpengaruh terhadap Internet Financial Reporting (IFR) pada pemerintah dikabupaten/kota di Sumatera Barat. 


\section{KESIMPULAN, KETERBATASAN DAN SARAN \\ Kesimpulan}

Berdasarkan hasil dari penelitian dan pengujian yang telah dibuat maka hasil penelitian ini kemudian dapat disimpulkan sebagai berikut :

1. Ukuran pemerintah di pengujian hipotesis tidak memliki berpengaruh terhadap Internet Financial Reporting (IFR) pada pemerintah kabupaten/kota di Sumatera Barat.

2. PDRB perkapita dalam pengujian hipotesis berpengaruh positif pada di Internet Financial Reporting (IFR) pada pemerintah kabupaten/kota di Sumatera Barat.

3. Belanja daerah dalam pengujian hipotesis berpengaruh terhadap Internet Financial Reporting (IFR) pada pemerintah kabupaten/kota di Sumatera Barat.

\section{Keterbatasan Peneliti}

Keterbatasan yang terdapat dalam melakukan penelitian ini adalah sebagai berikut:

1. Terdapat bahwa adanya rendahnya kemampuan variabel independen dalam penelitian, sehingga variabel dependen yang belum dapat dijelaskan secara luas pada variabel independen.

2. Sampel penelitian dipemerintah daerah kabupaten/kota yang digunakan hanya diambil dari kabupaten/kota yang ada di provinsi Sumatera Barat.

\section{Saran}

Berdasarkan kesimpulan dan keterbatasan penelitian diatas dapat diberikan saran sebagai berikut:

1. Peneliti dapat mengembangkan penelitian dengan melakukan variabel lainnya seperti tingkat penetrasi internet, indeks pembangunan masyarakat, opini audit, leverage, kompetisi politik, dan visibilitas media.

2. sebaiknya dicari variabel lain yang memperlihatkan kontribusi yang lebih signifikan terhadap Internet Financial Reporting (IFR).

3. Peneliti dapat menambah sampel pada penelitian seperti badan publik, pemerintah provinsi atau pengambilan sampel serta menggunakan periode dari tahun yang lebih lama agar melihat perkembangan yang ada.

\section{DAFTAR PUSTAKA}

Agustin, Henri; Arza, Fefri Indra. (2019). Potrait of Accountability and Transparency in Local Budget Management by the Regional Government in West Sumatera Province, Indonesia: An Anomaly in Digital Era. $4^{\text {th }}$ Padang International Conference on Education, Economics, Business and Accounting (PICEEBA-2 2019). Padang. 154-166.

Alhajriana et al, (2017). Faktor-Faktor Yang Mempengaruhi Pengungkapan Informasi Akuntansi Di Internet Oleh Pemerintah Daerah. Diponegoro Journal of Accounting, 2(3): 1-11.

Agustin, Henri. (2014). Publikasi Dokumen Pengelolaan Anggaran pada Website Pemkab/Pemkot di Propinsi Sumatera Barat. Seminar Nasional Aplikasi Teknologi Informasi (SNATI). Yogyakarta.

Cheng et al. (2000). Measuring The Quality of Corporate Financial Websites: A New Zealand Study. Paper presented at the $12^{\text {th }}$ Asian-Pasific Conference on International Accounting Issues. Beijing.

Government Finance Officers Association. (2009). Presenting Official Financial Document on Your Government's website. GFOA. Chicago 
Hartono, R, A. M dan Utaminingsih N.S.(2014). Faktor-Faktor yang Mempengaruhi Kelemahan Pengendalian Internal Pemerintah Daerah. Proceeding Simposium Nasional Akuntansi XVII. Lombok; 1-13.

Https://www.bps.go.id/. "produk domestik regional bruto lapangan usaha". Accessed on date November 10, 2019.

Idris. 2014. Analisis Data Kuantitatif. UNP Padang.

Intruksi Presiden No. 03 Tahun 2003 tentang Kebijakan Strategi Nasional Pengembangan eGovernment

Instruksi Mendagri No. 188.52/1797/SJ/2012 tentang Peningkatan Transparansi Pengelolaan Anggaran Daerah

Jensen \& Meckling. 1976. The Theory of The Firm: Manajerial Behaviour, Agency Cost, and Ownership Structure. Journal of Financial and Economic; 305-360

Kholifa. 2018. Determinan Praktik Internet Financial Reporting (IFR) dalam Website Pemerintah Daerah (Studi Empiris Pemerintah Kab/Kota Tahun 2016-2017). Yogyakarta :Universitas Islam Indonesia

Laswad, Fawzi dkk. 2005. Determinants of Voluntary Internet Financial Reporting by Local Government Authorities. Journal of Accounting and Public Policy, 24; 101-121

Maiyora. 2015. Pengaruh Karakteristik Pemerintah Daerah Terhadap Kinerja Keuangan Pemerintah Darah Kabupaten/Kota (Studi Empiris Kabupaten/Kota Di Pulau Sumatera). Pekanbaru: Fakultas Ekonomi Universitas Riau

Madiasmo (2009). Akuntansi Sektor Publik. Yogyakarta: Penerbit Andi.

Nosihana \& Yaya, 2016. Internet Financial Reporting Dan Faktor-Faktor Yang Mempengaruhinya Pada Pemerintah Kota Dan Kabupaten Di Indonesia. Jurnal Dinamika Akuntansi Dan Bisnis, 3(2): 89-104.

Novia, Siswita; Arza, Fefri Indra; Agustin, Henri. (2015). Studi Kebutuhan Informasi Pengguna Laporan Keuangan Pemerintah Kota Padang (Studi Empiris pada DPRD dan SKPD Kota Padang). Jurnal WRA, 3(1), 529-548.

Peraturan Pemerintah Nomor 71 Tahun 2010 dalam Standar Akuntansi Pemerintahan Nomor 02 tentang Laporan Realisasi Anggaran

Peraturan Presiden Republik Indonesia Nomor 95 Tahun 2018 tentang Sistem Pemerintahan Berbasis Elektronik (SPBE)

Peraturan Menteri Dalam Negeri Nomor 21 Tahun 2011 tentang Pedoman Pengelolaan Keuangan Daerah

Peraturan Menteri Dalam Negeri Nomor 3 Tahun 2017 tentang Pedoman Pengelolaan Informasi dan Dokumentasi (PPID) Kementrian Dalam Negeri dan Pemerintah Daerah

Pitri, Verawaty Dkk. 2017. Faktor-Faktor Penentu Transparansi Informasi Keuangan Daerah Melalui E-Government Pemerintah Kabupaten /Kota Di Sumatera Selatan. Palembang : Universitas Bina Dharma

Prabowo, Dkk. (2011). Analisis Faktor-Faktor yang Mempengaruhi Pelaporan Keuangan di Internet Secara Sukarela Oleh Pemerintah Daerah. Jurnal Universitas Diponegoro 1(1)

Puspita dan Martani. (2012). Analisis Pengaruh Kinerja Dan Karakteristik Pemda Terhadap Tingkat Pengungkapan Dan Kualitas Informasi Dalam Website Pemda.

Rahman, Sutaryo dan Budiatmanto. (2015). Determinan Internet Financial Local Governmen Reporting di Indonesia. Simposium Nasional Akuntansi XVI. Manado 
Sari. 2016. Pengaruh Ukuran Pemerintah Daerah, PAD, Leverage, Dana Perimbangan Dan Ukuran Legislatif Terhadap Kinerja Keuangan Pemerintah Daerah (Studi pada Kab/Kota Pulau Sumatra). Pekanbaru: Fakultas Ekonomi Universitas Riau

Sugiyono.(2010). Metode Penelitian Pendidikan Pendekatan Kuantitatif, Kualitatif dan R\&D. Bandung: Alfabeta

Style, A.K.,\& Tennyson, M (2007) The accebility of Financial Reporting of U.S Municipalities On The Internet. Journal of Public Budgeting, Accounting \& financial Management. United State

Sumarjo. 2010. Pengaruh Karakteristik Daerah terhadap Kinerja Keuangan Pemerintah Daerah. Skripsi. Surakarta: Fakultas Ekonomi Universitas Sebelas Maret

Undang Nomor 14 Tahun 2008 tentang Keterbukaan Informasi Publik

Undang Nomor 23 Tahun 2014 tentang Pemerintahan Daerah

Verawaty. 2015. Determinan Aksesibilitas Internet Financial Reporting Melalui E-Government Pemerintah Daerah Di Indonesia. Medan

Wau, I. 2015. Faktor-faktor yang Mempengaruhi Ketersediaan Dan Keteraksesan Internet Financial Reporting (IFR) oleh Pemerintah Daerah 